\section{Women's rights at 'Einstein'}

SIR-Leonard Minsky and Rita I. Kaplan (Nature 339, 10;1989) suggest that there is a contradiction between my opinion on the specific case of Sobel vs. Yeshiva University, and the sentiments of the letter on the same page written by myself and nine other women faculty members of the Albert Einstein College of Medicine in response to Joseph Palca's unsubstantiated statement (Nature 338, 192; 1989) that "Einstein has had a poor track record in its attitude towards female faculty".

My position, reflected in my published remarks to the senate as chairperson of the senate committee, was to urge the Yeshiva administration to settle the case without further costly litigation. This was formalized in a unanimous resolution by the senate to that effect. Some of my remarks are quoted out of context, and convey a false impression that they arose from my "anger with the continuing pattern of discrimination" at Einstein. Rather, the words expressed my disappointment at the handling of the senate resolution by the administration, and the failure of the administration to undertake steps to settle the case promptly.

The Sobel case illustrates the difficulties at Einstein and other US medical schools that stemmed from, and reflected, the then current and historical national attitudes on issues of employment and salaries for women professionals. In 1972, a few years before the class suit was filed, the women's committee of the Einstein faculty-student senate made a comparative study of employment of women at Einstein and other medical schools (how many academic senates had women's committees then?). I was chairperson of that committee. While pointing out that much had to be done to rectify the differential salaries for women, and making specific recommendations on recruitment, promotions, salary adjustments, etc., the committee found that Einstein had more women on its faculty, and more women as students, than most other medical schools. In the ensuing years Einstein, pressed by a vigilant and forward-looking faculty, moved to rectify the deficiencies pointed out in the report. Even today, after a decade of increasing opportunities for women in academic medicine, Einstein leads the major medical schools in the numbers of female faculty and students (based on data from the Association of American Medical Colleges and New York State Education Department). At Einstein, women are recruited (at the same salary levels) and promoted to senior rank under the same criteria as those governing recruitment and promotion of men. That is why Einstein leads the other medical schools in numbers of women in the senior ranks of

\section{associate and full professors.}

Most importantly, the faculty here is fully united in regard to women's issues and is constantly vigilant concerning wrong-doing to any faculty member whether male or female. In this imperfect world we are not always successful in monitoring and correcting inequities, but we persist; hence my remarks to the Senate quoted in the two letters.

Finally, I want to urge Mr Minsky and Ms Kaplan not to make the mistake of thinking that women such as I are automatically weak and incapable of independent and spontaneous opinion.

Olga O. BLUMENFELD

Department of Biochemistry,

Albert Einstein College of Medicine,

New York,

New York 10461, USA

\section{Wrong number}

SIR-I agree wholeheartedly with your argument for the autonomy and academic freedom of institutions (Nature 333, 445; 1989 ), but I have to differ with you on a small question of numbers. There are 29 designated polytechnics in England and one in Wales. The English polytechnics, along with 55 colleges of higher education, are now independent corporations, largely funded through the PCFC (Polytechnics and Colleges Funding Council). In addition, two Scottish central institutions have adopted the term 'polytechnic', namely Napier Polytechnic of Edinburgh and Glasgow College, which styles itself 'a Scottish Polytechnic'.

A. J. G. FRENCH Committee of Directors of Polytechnics, Kirkman House.

12-14 Whitfield Street, London W1P 6AX, UK

\section{Scientific fraud}

SIR-I believe it is unlikely that the professional perpetrators of scientific fraud are mentally ill, or seek self-destruction (Nature 339, 91; 1989). These men are brilliant in scientific research, and as Efraim Racker comments, excellent in other fields, too. Why should such men commit fraud? Perhaps there is a plausible explanation

The eventual 'professional fraud-maker' is a smart and an intelligent person who has always done brilliantly in school and colleges. He is much aware of his competence, and, used to success as he is, expects instant results and recognition in research too. The firm conviction that he is brilliant, along with the belief that brilliance alone begets success, exerts immense pressure on him to prove himself at everything he attempts; and if the results do not come soon enough, this desperate smart scientist resorts to 'short cuts'. The perpetrator of fraud is aware that his 'sensational' results will be checked and proved wrong in the course of time, but by then he has capitalized on them. He already enjoys the reputation of being a brilliant scientist and reasons that people will more easily accept his frauds initially, and later the explanations that he either made an honest mistake (brilliant scientists are known to have made silly mistakes!) or was victimized by a jealous colleague. He therefore does not intend to be caught.

Perhaps for this reason, Racker's presumption that his brilliant student was ill and that there was no cure for his illness is unfounded. Scientific fraud is a crime, and like other crimes may emanate from ambiguous values of society. The problem needs to be analysed and possibly solved. Those who do science should not claim that it cannot be.

SUDHIR MARATHE

University of Cambridge,

Department of Genetics,

Downing Street,

Cambridge CB2 3EH, UK

\section{Too high a price}

SIR-I was pleased to read the favourable mention given to my contribution by Stephen C. Inglis in his review (Nature 339, 188; 1989) of RNA Genetics (CRC Press, 1989). I was at the same time distressed to learn that hardly anyone else will ever read it, as the outrageous price of the 3-volume set $(\$ 425)$ puts it out of reach of virtually all individuals and laboratories as well as most libraries. Lest I give the impression that $\mathbf{I}$, as an author, am in a privileged position in this regard, I hasten to point out that the publishers, in their generosity, provided me with only the one $17-\mathrm{mm}$ thick volume containing my own chapter. Nor was the 'honorarium' paid me by the publishers sufficient to purchase even one of the other two volumes. Like nearly everyone else, I will never read most of this potentially useful work.

The moral is clear. Had I been aware of the price of the book, I would never have agreed to contribute to it. In future, I will always find out the pricing and distribution policy of the publisher of any work to which I am asked to contribute, and will deal only with those who make an honest attempt to make the efforts of their workers accessible to the relevant readership. I urge all readers, as prospective authors, to do the same. Perhaps we can make a dent in the overpublication of such excessively expensive and unread books.

Department of Molecular Biology JOHN M. COFFIN

\section{and Microbiology,}

Tufts University School of Medicine, 136 Harrison Avenue

Boston, Massachusetts 02111, USA 